\title{
Integrated monitoring of sustainable development
}

Citation for published version (APA):

van Zeijl-Rozema, A., \& Martens, P. (2011). Integrated monitoring of sustainable development. Sustainability: The journal of Record, 4(4), 199-202. https://doi.org/10.1089/SUS.2011.9673

Document status and date:

Published: 01/01/2011

DOI:

10.1089/SUS.2011.9673

Document Version:

Publisher's PDF, also known as Version of record

Document license:

Taverne

\section{Please check the document version of this publication:}

- A submitted manuscript is the version of the article upon submission and before peer-review. There can be important differences between the submitted version and the official published version of record.

People interested in the research are advised to contact the author for the final version of the publication, or visit the DOI to the publisher's website.

- The final author version and the galley proof are versions of the publication after peer review.

- The final published version features the final layout of the paper including the volume, issue and page numbers.

Link to publication

\footnotetext{
General rights rights.

- You may freely distribute the URL identifying the publication in the public portal. please follow below link for the End User Agreement:

www.umlib.nl/taverne-license

Take down policy

If you believe that this document breaches copyright please contact us at:

repository@maastrichtuniversity.nl

providing details and we will investigate your claim.
}

Copyright and moral rights for the publications made accessible in the public portal are retained by the authors and/or other copyright owners and it is a condition of accessing publications that users recognise and abide by the legal requirements associated with these

- Users may download and print one copy of any publication from the public portal for the purpose of private study or research.

- You may not further distribute the material or use it for any profit-making activity or commercial gain

If the publication is distributed under the terms of Article $25 \mathrm{fa}$ of the Dutch Copyright Act, indicated by the "Taverne" license above, 


\title{
Integrated Monitoring of Sustainable Development
}

\section{Cooperation between Maastricht University and the Regional Government}

\author{
By Annemarie van Zeij|-Rozema and Pim Martens
}

\begin{abstract}
Indicators by themselves tell us little about how well a system is doing in relation to the goal of sustainability. The real challenge is not to identify indicators - there are hundreds of good lists - but to seek out the best way to put all of them to work. The INSURE project, carried out in four case study regions in Europe among which was the Limburg region of the Netherlands, attempted to develop an adaptive indicator framework for integrated monitoring of sustainable development. During the project, it became clear that indicators are not only more meaningful when seen within the whole system, but also that science and policy have different, but complementary, roles to play.
\end{abstract}

\section{Introduction}

The Province of Limburg in the Netherlands together with the International Centre on Integrated Assessment and Sustainable Development of Maastricht University applied an adaptive indicator framework for measuring regional sustainable development. It is adaptive in the sense that it allows for the inclusion of regional characteristics and different methods for selecting indicators. This so-called INSURE method, developed to find meaningful indicators at the regional level, was implemented in four case-study regions during the years 2004 to 2007: Antalya (Turkey), Limburg (The Netherlands), Lombardy (Italy), and Pardubice
(Czech Republic). ${ }^{1}$ In addition to measuring the "symptoms of unsustainability" through individual sustainable development indicators, INSURE sought to get to the "causes" with a better fundamental understanding of the region as a system.

The main goal of the INSURE project was to find region-specific indicators and to combine them in such a way that they could provide an integrated view of regional sustainability. In Limburg the regional administration wanted to conduct a sustainability assessment from a perspective that would enable it to fulfill a biennial monitoring requirement. An expert group consisting of provincial administration staff was asked to conduct an assessment using the INSURE method.

\section{Steps Toward Implementa- tion}

The implementation of the INSURE method in Limburg was carried out in small steps. The most important goal of these steps was that the image of society created in the process should be representative. In order to ensure representativeness, an interdisciplinary project team of policy officials of the Province of Limburg was brought together. Each policy area was represented by one employee in the project team. The combination of policy sectors present aimed to

International Center for Integrated Assessment and Sustainable Development (ICIS),

Maastricht University, The Netherlands.

This study is based on measuring the sustainable development of the Limburg society

by means of the INSURE model. 
mirror the Limburg society. The project team has come together several times to discuss past and future steps. The discussions revealed that each step should not be too large. This was especially important to maintain the overview and understand what each step meant.

The first step in applying the INSURE method was the identification of a vision for sustainable development. The vision determines how the organization looks at a sustainable society and determines the regional framework of indicators. However, neither a framework nor a vision existed for Limburg. It was at best possible to assemble a partial vision. According to the provincial administration:

[S] ustainable development has in theory five dimensions: ecological, economic, sociocultural aspects, long-term effects and effects elsewhere. Furthermore... development must take place in such a way that the value of each form of capital increases and that the increase of one type of capital does not reduce the value of the other capitals. [translation by author]

The coalition agreement, a document that describes the overall political priorities for the period 2007-2011, explicitly recog- nizes the first three domains cited above (i.e., ecology, economy, and society) and their interconnectedness and regards sustainable development as an important pathway. However, sustainable development is still not made concrete and it is not supported by clear goals. The project team for the Limburg monitor could not use a vision of sustainability and therefore used the general principles of sustainability: economic, social and ecologic capital. This approach had earlier been used for Limburg's spatial plan and was endorsed by the project team. The team did not want to interfere with what its members saw as a role for policy makers by setting their own priorities for sustainable development in Limburg. Therefore, the regional framework remained rather indistinct.

After establishing a working definition of sustainable development, the next step was to conduct a qualitative system analysis. The qualitative system analysis determines the most important issues in society. Within the spatial planning process that was conducted almost 10 years before attributes (similar to the key issues within a society) for each of the domains had been defined (see Fig. 1).

This list of attributes or key issues was updated by the project team. Next came the job of relating each of the key issues to the others in order to establish causal relationships, with weights assigned to them based on their strength and how they contributed to sustainability. Each team member then identified, in the form of a causal map, the relations that were present in his or her policy sector, including the cross-sectoral issues (see Fig. 2). This made it possible to link different maps.

After each member completed a causal map, the different maps were merged. The end result was a network, or web, of relations giving a picture of Limburg society. One issue that became clear is that population size is related to many other factors. A change in population size will therefore have an important impact in society. Given the fact that Limburg is an area where the population is already decreasing and aging, this should be considered an important driving force. From the systems web and corresponding model, the most important topics within the region could be determined. These were rechecked by the project team for coherence and representativeness. Some attributes were deleted because the experts did not judge them as being significant and others, such as noise and odor pollution, were added because they were seen as important elements of today's society.

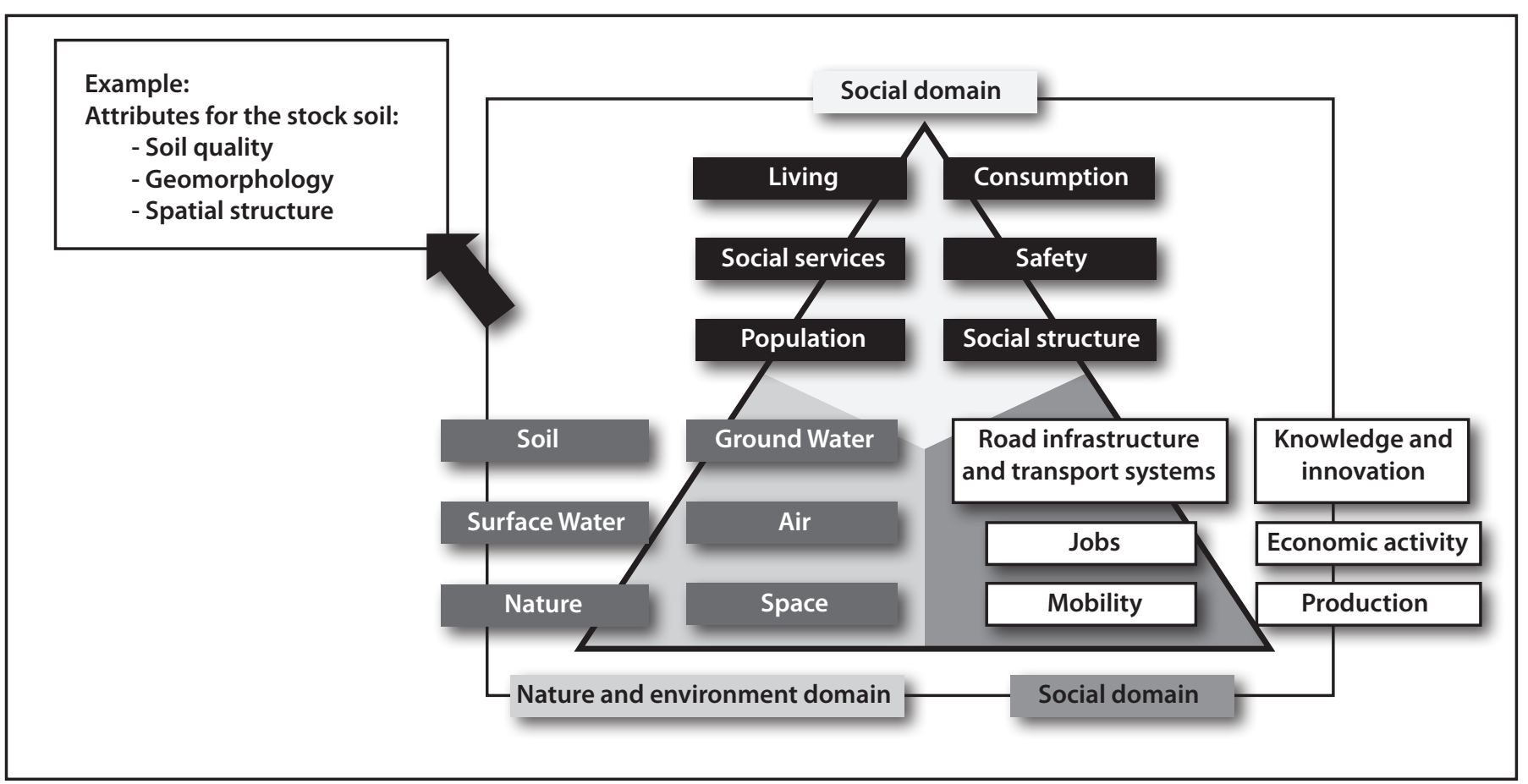

Figure 1. Domains, stocks, and an example of attributes. (Reprinted with permission from Roijen and Zeijl-Rozema. ${ }^{2}$ ) 


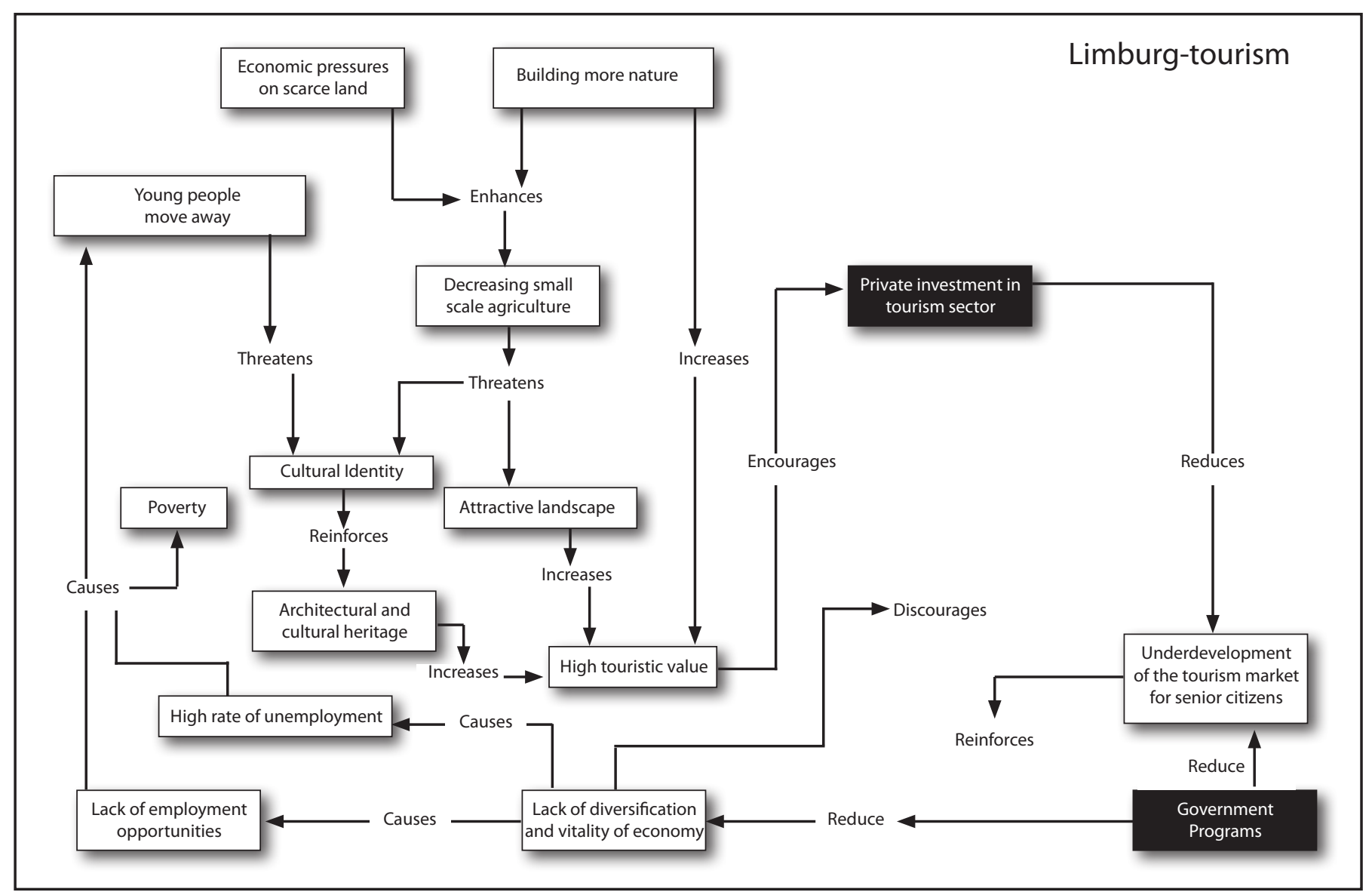

Figure 2. Example of a causal map for tourism in Limburg.

The next step was to assign indicators to each attribute and interprete the results. Here again we ran into trouble because without a clear vision and goals it is very difficult to judge if a development is a good one or not. A way to get around this, because we did not have decision-makers in our team, was to assess each indicator within the domain it was placed. For instance economic growth can happen at the cost of ecological qualities, while it is good for the economic domain. As economic growth was in our assessment part of the economic capital, an increase in growth was judged to be positive. So for all of the indicators the group decided if a higher number meant a positive or negative development from the perspective of sustainable development.

In Figure 3, the indicators are brought together visually in a pie chart. The degree of increase or decrease and the development of an attribute determine the color in the chart. The width of each box shows the relative influence the indicator has within the system. This overview shows that the Limburg society as a whole has developed positively neutral in recent years-the total of negative and positive developments are reasonably in balance. The ecological, economic, and social capital demonstrate this at the chart's center. Social capital shows a neutral development, from yellow to light yellow. The ecological capital is just on the wrong side of the middle: neutral negative. What is also striking is that nearly $55 \%$ of the diagram is occupied by economic capital, $25 \%$ by social capital, and $20 \%$ by ecological capital. Developments in economic capital are apparently strongly influencing the situation in Limburg.

\section{What Is the Usefulness of Such a Monitoring Exercise?}

The monitor shows the development of key elements in the regional system. Based on this information, the Provincial Executive and Provincial Parliament can check developments against policy goals: "Do we see the right developments?" It is also possible that the main bottlenecks in the integrated system assessment have little or no priority in the provincial policy. Then the Provincial Parliament could bring this up by asking if the policy priorities are the right ones. As the Limburg monitor is a public document, even a citizen's initiative could place topics of concern on the political agenda. Although we know that the Limburgmonitor has been used as an information source, we do not know of occasions where it was used to fuel the debate on agenda setting.

\section{What Did We Learn from This Cooperation?}

For such an exercise an interdisciplinary group of people is important if a comprehensive overview of society needs is to be made. It can be debated whether a more extensive group, including society representatives, should have been used. Furthermore, the group wanted small steps in order to understand what was going on. They reacted positively to using a system (capitals and attributes) that they were familiar with. 


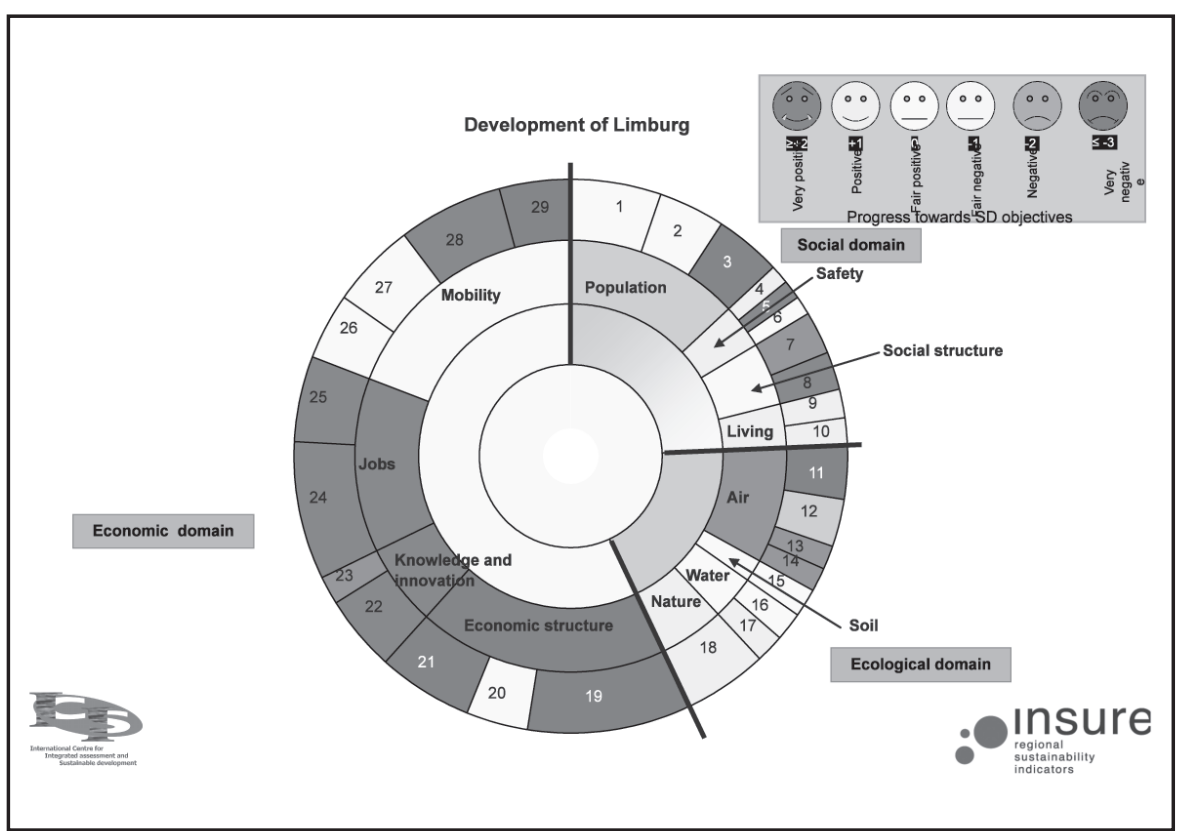

Figure 3. The results of monitoring Limburg in 2007.

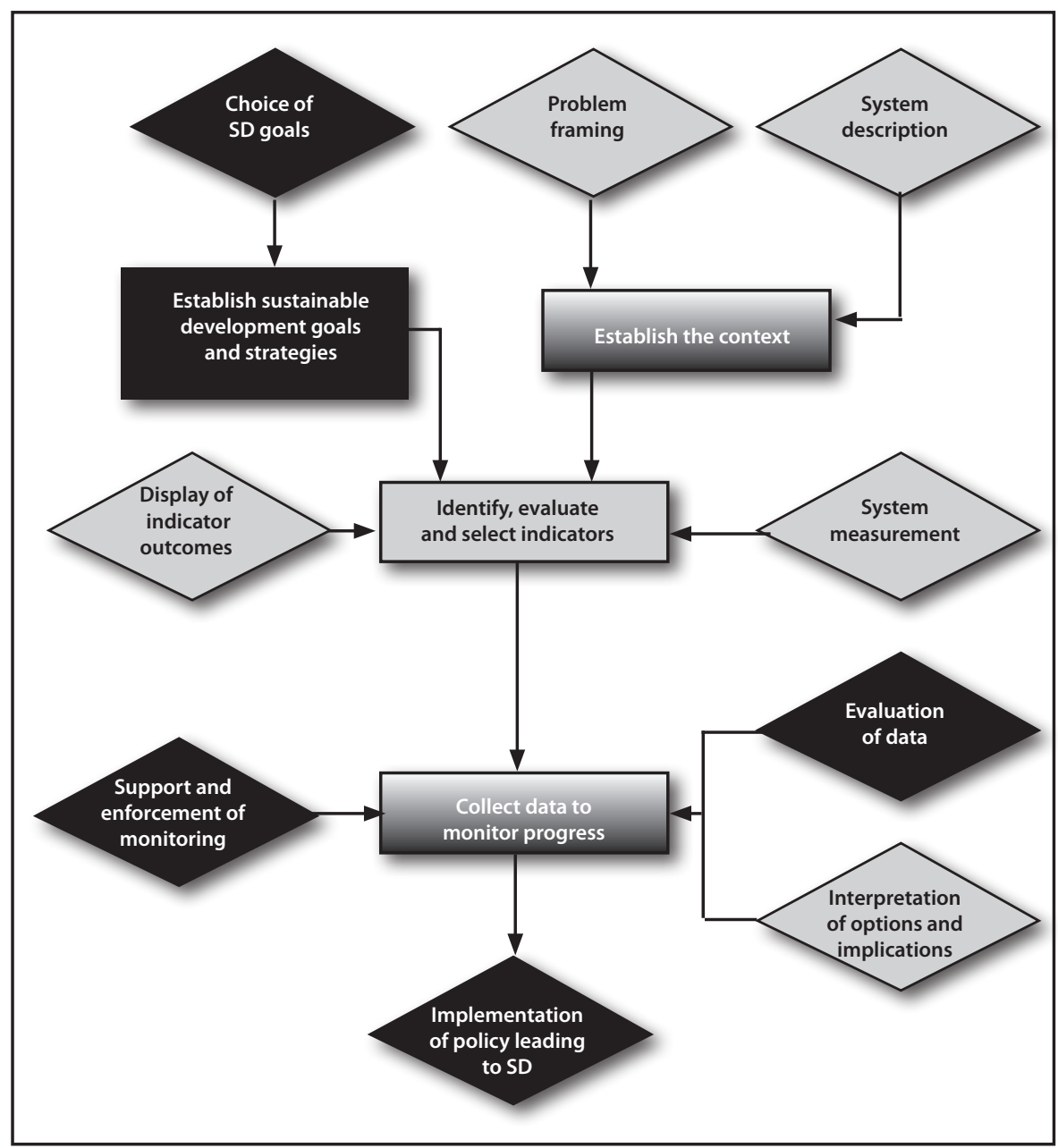

Figure 4. The role of policy and science in the various stages of monitoring sustainable development (policy, black; science, light grey; steps in process, rectangles; roles of actors, diamonds). (Reprinted with permission from Zeijl-Rozema van and Martens. ${ }^{3}$ )
A last issue to be mentioned is the fact that this project made clear that at all stages of measuring sustainable development (Fig. 4), the involvement and cooperation of relevant policy makers and technical experts, are essential. The problem of creating a vision and interpreting indicators could not be overcome by using an expert group that had no political mandate for defining sustainable development in this regional context because it was neither representative of the population nor an elected body with delegated powers from the residents of Limburg. Given such hindsight, we would admit that enhanced cooperation among these participants from the beginning would likely have led to a more meaningful assessment.

\section{References}

1. INSURE (Flexible Framework for Indicators for Sustainability in Regions, Using System Dynamics Modelling). Available at: http://www.icis.unimaas.nl/projects/insure

2. Roijen D, and Zeijl-Rozema van A. Het meten van duurzame ontwikkeling van de Limburgse samenleving middels het INSURE model. Department of Strategy and Innovation. Maastricht, Province of Limburg, 2008, pp. 1-22.

3. Zeijl-Rozema van A, and Martens P. An adaptive indicator framework for monitoring regional sustainable development: a case study of the INSURE project in Limburg, The Netherlands. Sustainability: Sci Pract Pol 2010;6(1):6-17.

Address correspondence to:

Annemarie van Zeijl-Rozema, Ph.D.

and Pim Martens, Ph.D.

International Center for Integrated Assessment and Sustainable Development (ICIS)

Maastricht University

P.O. Box 616

6200 MD Maasticht

The Netherlands

\section{Email:}

Annemarie van Zeijl-Rozema: a.vanzeijl@maastrichtuniversity.nl

Pim Martens:

p.martens@maastrichtuniversity.nl 